\title{
DAMPAK DISTRIBUSI ZAKAT DALAM MENGURANGI KEMISKINAN BERDASARKAN MODEL CIBEST (STUDI KASUS DI BAZNAS KOTA PEKANBARU)
}

\author{
Wahyi Busyro' \& Dwita Razkia ${ }^{2}$ \\ $1 \& 2$ Fakultas Studi Islam, Universitas Muhammadiyah Riau \\ Email:wahyi.busyro@umri.ac.id
}

\begin{abstract}
ABSTRAK
Ada banyak program yang dijalankan pemerintah untuk menanggulangi kemiskinan ini, diantaranya bantuan langsung tunai, penciptaan lapangan kerja, sembako murah dan lainnya. Harapannya dengan adanya program ini masalah kemiskinan bisa teratasi. CIBEST merupakan singkatan dari Center for Islamic Business and Economic Studies, dimana model ini digunakan untuk megukur metode kedua dimensi tersebut, spiritual dan material (ekonomi) dan mengombinasikannya untuk mengetahui keadaan rumah tangga miskin tanpa atau dengan adanya bantuan zakat. Penelitian ini dilakukan di Kota Pekanbaru dengan menggunakan metode penelitian CIBEST. Berdasarkan hasil penelitian ini diperoleh jumlah rumah tangga mustahik yang berada pada kategori rumah tangga sejahtera mengalami peningkatan dari 0.25 menjadi $0.76 \%$. Indeks kemiskinan material menggambarkan jumlah rumah tangga mustahik yang masuk dalam kategori miskin secara materialnya namun kaya secara spiritual juga mengalami penurunan dari 0.56 menjadi $0.21 \%$. Indeks kemiskinan spiritual menggambarkan jumlah rumah tangga mustahik yang masuk ke dalam kategori miskin secara spiritual tetapi kaya secara material. Indeks kemiskinan spiritual rumah tangga mustahik mengalami perubahan dari 0.08 menjadi $0.01 \%$. Indeks kemiskinan absolut menggambarkan jumlah rumah tangga mustahik yang masuk ke dalam kategori miskin secara material maupun secara spiritual. Rumah tangga pada kategori ini mengalami perubahan dari 0.11 menjadi $0.02 \%$.
\end{abstract}

Kata kunci : Zakat, Kemiskinan, CIBEST.

\begin{abstract}
There are many programs implemented by the government to mitigate poverty, such as the Unconditional Cash Transfer Program (BLT), creating employment opportunities, the Cheap Staple Food program, etc. These programs are expected to be able to solve poverty problems. CIBEST stands for Center for Islamic Business and Economic Studies. It is used for measuring the method of two dimensions (spiritual and material/economy) and combining them to know the condition of poor households with or without zakat assistance. This study was conducted in Pekanbaru City using the CIBEST model. The result of this study showed that the total Mustahik household (Zakat recipient) in the welfare household category was increasing from $0.25 \%$ to $0.76 \%$. The index of material poverty illustrated that the total Mustahik household in the poor category, materially poor yet spiritually rich, was also decreasing from $0.56 \%$ to $0.21 \%$. The index of spiritual poverty illustrated that the total Mustahik household in the poor category, spiritually poor yet materially rich, was decreasing from $0.08 \%$ to $0.01 \%$. The absolute poverty index illustrated that the total Mustahik household in the poor category, spiritually and materially, was decreasing from $0.11 \%$ to $0.02 \%$.
\end{abstract}

Keywords: Zakat, Poverty, CIBEST. 


\section{PENDAHULUAN}

Kemiskinan merupakan salah satu masalah besar yang dihadapi oleh beberapa Negara, termasuk salah satunya adalah Negara Indonesia. Kemiskinan tidak hanya diukur perekonomian, namun

juga dari pendidikan, sosial, kesehatan dan lainya. Kota Pekanbaru merupakan salah satu kota yang berada di Provinsi Riau, berdasarkan Data di Pekanbaru dalam tiga tahun terakhir adalah sebagai berikut :

Tabel 1. Data Penduduk Miskin Di Kota Pekanbaru

\begin{tabular}{ccc}
\hline No. & Tahun & $\begin{array}{c}\text { Jumlah Penduduk Miskin } \\
\text { (dalam ribuan jiwa) }\end{array}$ \\
\hline 1 & 2015 & 33,76 \\
\hline 2 & 2016 & 32,49 \\
\hline 3 & 2017 & 33,09 \\
\hline
\end{tabular}

Sumber : BPS (2018)

Jika dilihat dari data di atas jumlah penduduk miskin itu mengalami kenaikan pada tahun 2017 yaitu sebesar 33,09 (dalam ribu jiwa). Bagi pemerintah ini merupakan tantangan yang harus segera diselesaikan. Ada banyak program yang dijalankan pemerintah untuk menanggulangi kemiskinan ini, diantaranya bantuan langsung tunai, penciptaan lapangan kerja, sembako murah dan lainnya. Harapannya dengan adanya program ini masalah kemiskinan bisa teratasi.

Islam merupakan agama yang Rahmatan Lil Alamin, yang memberikan solusi bagi setiap umatnya. Dalam upaya penanggulangan kemiskinan ini, Islam memberikan solusi alternatif yaitu Zakat. Al-Quran Surat At-taubah ayat 60 Menjelaskan bahwa pendistribusian zakat untuk 8 golongan (asnaf), diantaranya Fakir, Miskin, Ibnu Sabil, Gharim, Fisabilillah, Muallaf, Budak. Fakir dan Miskin termasuk dalam golongan yang wajib mendapatkan pendistribusian zakat guna meringankan beban dan kesetaraan ekonomi. Zakat itu sendiri memiliki tiga dimensi : sosial, ekonomi, dan spiritual. Secara sosial, zakat dapat digunakan untuk mengurangi gap antara status kaya dan miskin. Secara ekonomi, zakat dapat digunakan untuk meningkatkan kesejahteraan dan memperbaiki tingkat ekonomi para mustahik. Sehingga zakat yang diberikan oleh muzakki bisa memperbaiki kehidupan mustahik. Dalam penyaluran zakat, badan amil zakat juga memiliki program yang bisa menunjang baik dari segi usaha maupun yang lainnya yang kemudian diharapkan juga memperbaiki spritual mustahik baik dari ibadah, akhlak dan lainnya. Untuk itu perlu menganalisis dampak penyaluran zakat terhadap kemiskinan spritual.

CIBEST merupakan singkatan dari Center for Islamic Business and Economic Studies, dimana model ini digunakan untuk megukur metode kedua dimensi tersebut, spiritual dan material (ekonomi) dan mengombinasikannya untuk mengetahui keadaan rumah tangga miskin tanpa atau dengan adanya bantuan zakat. Berdasarkan hal ini penulis ingin meneliti tentang dampak pendistribusian zakat dalam mengurangi kemiskinan berdasarkan model CIBEST ( Studi Kasus Pada BAZNAS Kota Pekanbaru).

\section{TINJAUAN PUSTAKA}

Kemiskinan adalah suatu intergrated concept yang memiliki lima dimensi, yaitu: kemiskinan (proper), ketidakberdayaan (powerless), kerentanan menghadapi situasi darurat (state of 
emergency),

ketergantungan

(dependence), dan keterasingan (isolation)

baik secara geografis maupun sosiologis (Prastyo, 2010).

Dalam Islam, kemiskinan dan kesenjangan dipandang sebagai sunatullah dan tidak bisa dihilangkan. Islam tidak pernah berbicara bagaimana menghilangkan kemiskinan, tetapi Islam berbicara mengenai bagaimana meminimalisir kemiskinan dan mencapai kesejahteraan. Salah satu instrumen yang dapat meminimalisir kemiskinan adalah dengan zakat (Hafidhudin \& Pramulya, 2008).

Penelitian Beik (2009) zakat menyebutkan bahwa zakat mampu mengurangi jumlah keluarga miskin dari 84 persen menjadi 74 persen. Kemudian dari aspek kedalaman kemiskinan, zakat juga terbukti mampu mengurangi kesenjangan kemiskinan dan kesenjangan pendapatan, yang di indikasikan oleh penurunan nilai P1 dari Rp 540.657,01 menjadi Rp 410.337,06 dan nilai I dari 0,43 menjadi 0,33 . Sedangkan ditinjau dari tingkat keparahan kemiskinan, zakat juga mampu mengurangi tingkat keparahan kemiskinan yang ditandai dengan penurunan nilai Indeks Sen (P2) dari 0,46 menjadi 0,33 dan nilai indeks FGT dari 0,19 menjadi 0,11 .

Penelitian Mushlihah (2016) memperoleh hasil bahwa pendistribusian dan pendayagunaan dana zakat memiliki dampak yang positif terhadap pendapatan rumah tangga mustahik. Setelah adanya bantuan dana zakat, jumlah rumah tangga mustahik yang berada pada kategori rumah tangga sejahtera mengalami peningkatan sebesar $640 \%$.

Menurut penelitian Mubarokah, Beik \& Irawan (2017) mengalami adanya bantuan zakat terbukti dapat menurunkan indeks kemiskinan material rumah tangga mustahik.

\section{METODE PENELITIAN}

Penelitian ini akan mengambil lokasi di Kota Pekanbaru. Waktu penelitian dilakukan dari bulan Februari 2020 .

Populasi dalam penelitian ini adalah mustahik kota pekanbaru, mustahik pada Baznas kota Pekanbaru ini berjumlah sebanyak 1585 orang.

Pemilihan sampel dengan menggunakan rumus Slovin yaitu :

$$
\begin{array}{ll}
\mathrm{n}= & \frac{1.585}{1+1.585}(0,10)^{2} \\
& \frac{1.585}{1+1.585} \quad(0.01) \\
& =\frac{1.585}{16.85} \\
& =94.0
\end{array}
$$

Berdasarkan hasil jumlah sampel ini maka peneliti membulatkan jumlah sampel sejumlah 100 orang.

Prosedur pengumpulan data dengan cara observasi, penyebaran kuesioner dan studi kepustakaan.

\section{Teknik Pengumpulan Data}

1. Penyebaran kuesioner yaitu memberikan kuesioner kepada responden yang terkait untuk mengisi dan menjawab dari kuesioner tersebut.

2. Mengklasifikasian kuesioner antara kuesinoer variabel independen dan dependen yang telah terkumpul sesuai dengan masalah yang telah ditetapkan.

3. Mengambil kesimpulan dari data yang telah diperoleh dari responden.

\section{Metode Analisis Data}

Indeks kemiskinan yang digunakan dalam menentukan kondisi rumah tangga mustahik adalah indeks 
kemiskinan Islami Center of Islamic Business and Economics Studies (CIBEST) Institut Pertanian Bogor (IPB) yang dikembangkan pada tahun 2015 oleh Beik dan Arsyianti (2015). Sedangkan untuk melihat perubahan yang terjadi pada pendapatan rumah tangga mustahik maka analisis yang digunakan adalah dengan menggunakan uji $\mathrm{t}$ berpasangan. Perhitungan yang digunakan sebagai dasar perhitungan dalam penelitian ini adalah nilai dari Material Value (MV) atau garis kemiskinan rumah tangga dan pendapatan rumah tangga per bulan. Material Value (MV) digunakan untuk mengukur standar minimal material yang harus dipenuhi oleh rumah tangga. Nilai MV diperoleh dengan mengalikan harga barang dan jasa yang dikonsumsi (Pi) dengan jumlah minimal barang dan jasa yang dibutuhkan (Mi). Secara matematis, MV dapat dirumuskan sebagai berikut:

$$
\mathrm{MV}=\text { Pi.Mi }
$$

Keterangan:

$$
\begin{aligned}
\text { MV = } & \text { Standar minimal material yang } \\
& \text { harus dipenuhi oleh rumah } \\
& \text { tangga (Rp atau mata uang } \\
& \text { lain) atau bisa disebut Garis } \\
& \text { Kemiskinan Material. } \\
\mathrm{Pi}= & \text { Harga barang dan jasa (Rp atau } \\
& \text { mata uang lain). } \\
\mathrm{Mi}= & \text { Jumlah minimal barang dan jasa } \\
& \text { yang dibutuhkan. }
\end{aligned}
$$

a. Indeks Kesejahteraan

$$
\text { Indeks kesejahteraan }
$$

digunakan untuk melihat rumah tangga yang masuk ke dalam kuadran I. Pada kuadran ini, rumah tangga dapat dikatakan sejahtera. Nilai $\mathrm{W}$ dapat diperoleh dengan formula:

$$
\mathrm{W}=\frac{w}{\mathrm{~N}}
$$

Keterangan:

$$
\begin{aligned}
\mathrm{W}= & \text { Indeks kesejahteraan; } 0 \\
\mathrm{~W}= & \begin{array}{l}
\text { Jumlah keluarga sejahtera } \\
\end{array} \\
& \begin{array}{l}
\text { kaya secara material dan } \\
\text { spiritual) }
\end{array} \\
\mathrm{N}= & \text { Jumlah populasi rumah tangga } \\
& \text { yang diobservasi }
\end{aligned}
$$

\section{b. Indeks Kemiskinan Material}

Indeks kemiskinan material (Pm) digunakan untuk melihat rumah tangga yang berada pada kuadran II atau miskin material. Nilai indeks kemiskinan material dapat diperoleh dengan formula:

$$
\operatorname{Pm}=\frac{M p}{\mathrm{~N}}
$$

\section{Keterangan:}

$\mathrm{Pm}=$ Indeks kemiskinan material; 0

$\mathrm{Mp} \quad=$ Jumlah keluarga yang miskin secara material namun kaya secara spiritual

$\mathrm{N}=$ Jumlah populasi (rumah tangga yang diamati)

c. Indeks kemiskinan spiritual (Ps)

Indeks ini digunakan untuk melihat rumah tangga yang masuk ke dalam kategori kuadran III atau kategori miskin spiritual. Nilai Ps dapat diperoleh dengan formula:

$$
\mathrm{Ps}=\frac{S P}{\mathrm{~N}}
$$

Keterangan:

Ps $\quad=$ Indeks kemiskinan spiritual; 0

$\mathrm{Sp} \quad=$ Jumlah keluarga yang miskin secara spiritual namun berkecukupan secara material

$\mathrm{N}=$ Jumlah populasi total rumah tangga yang diamati 
d. Indeks kemiskinan absolut $(\mathrm{Pa})$ digunakan untuk melihat rumah tangga yang berada pada kuadran IV atau miskin absolut. Nilai $\mathrm{Pa}$ dapat diperoleh dengan formula:

$$
\begin{array}{r}
\mathrm{Pa}=\frac{A p}{N} \\
N
\end{array}
$$

Keterangan:

$\mathrm{Pa}=$ Indeks kemiskinan absolut; $0 \mathrm{~Pa}$

Ap = Jumlah keluarga yang miskin secara spiritual dan juga material

$\mathrm{N}=$ Jumlah populasi total rumah tangga yang diamati

\section{Uji t-statistik Data Berpasangan}

Uji $\mathrm{t}$ atau $\mathrm{t}$ Test digunakan untuk melihat perubahan yang terjadi pada pendapatan rumah tangga mustahik sebelum dan sesudah adanya bantuan dana zakat. Uji $\mathrm{t}$ dilakukan dengan menggunakan perangkat lunak Statistical Analysis System (SAR) versi 9.1.3.

\section{Hipotesis}

H0 : Pendapatan rumah tangga mustahik setelah adanya bantuan dana zakat tidak berbeda nyata pada taraf $\alpha=5$ persen terhadap pendapatan rumah tangga mustahik sebelum adanya bantuan dana zakat.

H1: Pendapatan rumah tangga mustahik setelah adanya bantuan dana zakat berbeda nyata pada taraf $\alpha=5$ persen terhadap pendapatan rumah tangga mustahik sebelum adanya bantuan dana zakat.

\section{Kriteria Uji}

Nilai signifikansi > 0.05: terima $\mathrm{H}$, artinya pendapatan rumah tangga mustahik setelah adanya bantuan dana zakat tidak berbeda nyatapada taraf $\alpha=5$ persen terhadap pendapatan rumah tangga mustahik sebelum adanya bantuan dana zakat.

Nilai signifikansi < 0.05: tolak H0, artinya pendapatan rumah tangga mustahik setelah adanya bantuan dana zakat berbeda nyata pada taraf $\alpha=5$ persen terhadap pendapatan rumah tangga mustahik sebelum adanya bantuan dana zakat.

\section{HASIL DAN PEMBAHASAN}

Laporan Penerimaan Zakat pada Badan Amil Zakat Nasional Kota Pekanbaru 2017-2019

Tabel 2. Laporan Penerimaan Zakat di BAZNAS Kota Pekanbaru

\begin{tabular}{ccc}
\hline No & Tahun & Total Zakat \\
\hline 1 & 2017 & $5.201 .769 .425,-$ \\
\hline 2 & 2018 & $5.768 .727 .155,-$ \\
\hline 3 & 2019 & $6.279 .765 .215,-$ \\
\hline & Sumber : Baznas Kota Pekanbaru (2020)
\end{tabular}

Berdasarkan data dari laporan peneriman zakat di Badan Amil Zakat Nasional (Baznas) Kota Pekanbaru, dilihat dari tiga tahun terakhir mengalami peningkatan, dengan berbagai upaya sosialisasi yang dilakukan oleh BAZNAS masyarakat Kota Pekanbaru semakin mempercayai BAZNAS Sebagai salah satu amil di
Kota Pekanbaru.

\section{Karakteristik Mustahik}

Sampel dalam penelitian ini merupakan mustahik yang ada di BAZNAS Kota Pekanbaru dengan menggunakan rumus slovin maka diperoleh responden pada penelitian berjumlah 100 orang mustahik yang pernah menerima zakat dari BAZNAS 
Kota Pekanbaru. Adapun karakteristik mustahik nya adalah sebagai berikut:

Tabel 3. Karakteristik Mustahik

\begin{tabular}{|c|c|c|}
\hline Karakteristik & Jumlah & Persentase \\
\hline \multicolumn{3}{|l|}{ Jenis Kelamin } \\
\hline Laki-laki & 82 & 82 \\
\hline Perempuan & 18 & 18 \\
\hline \multicolumn{3}{|l|}{ Usia } \\
\hline$\overline{15-40}$ & 39 & 39 \\
\hline $41-60$ & 45 & 45 \\
\hline$>60$ & 19 & 19 \\
\hline \multicolumn{3}{|l|}{ Status Pernikahan } \\
\hline \multicolumn{3}{|l|}{ Belum Menikah } \\
\hline Menikah & 68 & 68 \\
\hline Janda/Duda & 32 & 32 \\
\hline \multicolumn{3}{|l|}{ Pendidikan } \\
\hline Tidak Sekolah & 5 & 5 \\
\hline SD & 42 & 42 \\
\hline SMP Sederajat & 43 & 43 \\
\hline SMA Sederajat & 9 & 9 \\
\hline$>$ SMA & 1 & 1 \\
\hline \multicolumn{3}{|l|}{ Pekerjaan } \\
\hline Tidak Bekerja & 23 & 23 \\
\hline Pedagang & 19 & 19 \\
\hline Buruh & 29 & 29 \\
\hline \multicolumn{3}{|l|}{ Karyawan } \\
\hline Cleaning Service & 17 & 17 \\
\hline IRT & 12 & 12 \\
\hline \multicolumn{3}{|l|}{ Ukuran Keluarga } \\
\hline $1-3$ orang & 30 & 30 \\
\hline 4-6 orang & 48 & 48 \\
\hline$>6$ orang & 22 & 22 \\
\hline \multicolumn{3}{|l|}{ Bantuan } \\
\hline Produktif & 13 & 13 \\
\hline Konsumtif & 87 & 87 \\
\hline
\end{tabular}

Sumber: Baznas Kota Pekanbaru (2020)

Berdasarkan tabel di atas diketahui bahwa mayoritas mustahik pada penelitian ini adalah laki laki sebanyak 82 orang, sedangkan perempuan sebanyak 18 orang. Jika dilihat dari status pernikahan mayoritas itu adalah 68 orang yang sudah menikah dan 32 orang itu berstatus janda/ duda. Dilihat dari segi usia, mustahik berumur 41-60 yang mayoritas penerima mustahik dengan tingkat pendidikan tertinggi itu pada tingkat SMP dan SMA dengan mayoritas status pekerjaan mustahik adalah buruh yang menerima bantuan zakat yang bersifat konsumtif.

Perolehan hasil karakteristik mustahik ini bisa analisa bahwa mayoritas mustahik adalah memiliki pekerjaan buruh yang berstatus sebagai kepala keluarga yang berusia $>40$ tahun. Adapun jenis bantuan yang diperoleh oleh mustahik adalah Zakat Konsumtif. 
BAZNAS Kota Pekanbaru memiliki beberapa program penyaluran zakat sebagai berikut :

1. Bantuan kebutuhan hidup Mustahik

2. Bantuan kesehatan (bantuan pengobatan jalan)

3. Bantuan pendidikan (biaya tunggakan sekolah dll)

4. Bantuan Ibnu Sabil (bantuan untuk orang terlantar)

5. Bantuan Gharimin

6. Bantuan Muallaf

7. Bantuan fisabilillah

Analisis Dampak Distribusi Zakat Dalam Mengurangi Kemiskinan Berdasarkan Model CIBEST (Studi Kasus Di Baznas Kota Pekanbaru)

Berdasarkan hasil yang diperoleh dari mustahik maka diketahui bahwa penyaluran dana zakat memiliki dampak terhadap pendapatan rumah tangga mustahik.

Dampak ini bersifat positif bagi mustahik yaitu peningkatan pendapatan mustahik dimana sebelum adanya bantuan zakat rata rata pendapatan rumah tangga mustahik adalah $\mathrm{Rp} 1.554 .000$ setelah adanya pendistribusian zakat ada peningkatan sebesar Rp 2.082.002.

Model CIBEST merupakan Model untuk menguji tingkat kemiskinan masyarakat bukan hanya kemiskinan materil namun juga spritual mustahik. Skor spritual pada mustahik dalam penelitian ini diperoleh dari Uji T Statistik berpasangan hasilnya adalah signifikan sebesar 0.0000 artinya terdapat perbedaan skor spiritual mustahik tanda dan adanya zakat. Artinya dengan adanya zakat perbedaannya bukan hanya peningkatan ekonomi keluarga saja namun juga secara spritual. Spritual yang diukur melalui model CIBEST ini adalah Shalat, Puasa, Zakat, Lingkungan Rumah Tangga dan Kebijakan Pemerintah.

\section{Analisis Kuadran CIBEST Tanpa dan dengan Adanya Bantuan Zakat dari Baznas Kota Pekanbaru}

Model CIBEST terdiri dari empat area yaitu : Area Kesejahteraan (Kuadran 1), Area Miskin Material, Area Miskin Spiritual, dan Area Miskin Absolut. Hasil yang diperoleh pada penelitian dengan sampel 100 mustahik adalah sebagai berikut :

Berdasarkan Model CIBEST ini maka bisa dianalisis bahwa sebelum adanya bantuan zakat tingkat Kemiskinan pada masing masing kuadran terlihat pada tabel di atas. Kuadran 1 area sejahtera ada 25 Rumah Tangga, Kuadran 2 Miskin Materil sebanyak 56 Rumah Tangga, sementara pada kuadran 3 Miskin Spritual sebanyak 8 Rumah Tangga dan Miskin Absolut pada kuadran 4 sebanyak 11 Rumah Tangga.

Setelah memperoleh bantuan dana zakat maka berdasarkan data yang diperoleh sesuai dengan tabel di atas mengalami perubahan pada area kuadran CIBEST. Area Sejahtera sebanyak 76 Rumah Tangga, pada kuadran 2 area Miskin Material sebanyak 21 Rumah Tangga mengalami penurunan dimana sebelum menerima zakat ada sebanyak 56 Rumah Tangga, artinya ada rumah tangga yang mengalami peningkatan ekonomi karena adanya bantuan zakat. Sementara pada area 3 miskin spritual ada 1 Rumah Tangga, kuadran ini juga mengalami penurunan setelah adanya bantuan zakat artinya dengan adanya bantuan zakat ini ada rumah tangga yang mengalami peningkatan secara spritual. Pada kuadran 4 miskin absolut sebanyak 2 Rumah Tangga.

\section{Analisis Dampak Distribusi Zakat Terhadap Kemiskinn Spritual Mustahik}

Kemiskinan Spritual yang digunakan pada model CIBEST ini menggunakan 5 (lima) variabel yaitu 
shalat, puasa, zakat dan infak, lingkunagn keluarga, dan kebijakan pemerintah. Hasil dari pengolahan data skor spiritual mustahik diperoleh hasil signifikansi sebesar 0.000. Nilai signifikansi lebih kecil dari 5\%. Artinya terdapat perbedaan skor spiritual mustahik tanpa dan dengan adanya bantuan zakat.

Dalam istilah psikologi ada yang dinamakan psikologi prososial yaitu tingkah laku yang muncul dari apa yang telah didapatkannya dari lingkungan sosial. Perilaku prososial bisa dimulai dari tindakan altruism tanpa pamrih sampai tindakan yang dimotivasi oleh pamrih atau kepentingan pribadi. Zakat jika dilihat dari kacamata psikologi adalah merupakan stimulus dan juga respon dari tindakan prososial atau altruism yang bisa didorong oleh tiga motif sekaligus yaitu biogenesis, sosiogenesis, dan teogenesis. Motif biogenesis adalah tindakan individu untuk pemenuhan rasa lapar, haus, dan seksualitasnya. Motif sosiogenesis adalah tindakan yang muncul dari hasil interaksi sosial manusia dengan lingkungan sekitarnya. Motif teogenesis merujuk pada dorongan pemenuhan rasa tanggung jawab terhadap Tuhan. Secara psikologis seseorang butuh pendorong atau stimulus untuk memotivasi munculnya perilaku prososial. Dalam penelitian ini zakat menjadi pendorong atau stimulus para mustahik untuk meningkatkan spiritualnya atau meningkatkan hubungan dengan Allah SWT. Para mustahik dengan menerima zakat secara langsung dapat memenuhi kebutuhan biogenesisnya yaitu makan, minum,dan kesejahteraan lainnya. Hal ini mendorong munculnya motif sosiogenesis dan teogenesis, karena merasa sudah dibantu oleh orang lain melalui zakat maka merasa perlu memperbaiki diri baik itu perilaku dengan orang lain maupun memperbaiki hubungan dengan Allah SWT.

\section{Analisis Indeks Kemiskinan CIBEST}

Indeks kemiskinan Islami yang terdapat dalam model CIBEST terdiri atas indeks kesejahteraan, indeks kemiskinan material, indeks kemiskinan spiritual, dan indeks kemiskinan absolut. Berdasarkan hasil analisis kuadran CIBEST, telah diketahui jumlah rumah tangga yang masuk dalam masing-masing kategori. Indeks Kemiskinan CIBEST diperoleh sebagai berikut :

Tabel 4. Hasil Uji Validitas Motivasi

\begin{tabular}{llll}
\hline Indeks CIBEST & Tanpa Zakat & Dengan Zakat & Perubahan \\
\hline $\mathrm{W}$ & 0.25 & 0.76 & 0.51 \\
\hline $\mathrm{Pm}$ & 0.56 & 0.21 & $(0.35)$ \\
\hline $\mathrm{Ps}$ & 0.08 & 0.01 & 0.07 \\
\hline $\mathrm{Pa}$ & 0.11 & 0.02 & 0.09 \\
\hline
\end{tabular}

Sumber : Data Olahan (2020)

Dampak dari pendistribusian zakat ini kepada mustahik mengalami peningkatan baik itu dari segi spritual maupun materil. Berdasarkan hasil penelitian ini diperoleh jumlah rumah tangga mustahik yang berada pada kategori rumah tangga sejahtera mengalami peningkatan dari 0.25 menjadi $0.76 \%$. Indeks kemiskinan material menggambarkan jumlah rumah tangga mustahik yang masuk dalam kategori miskin secara materialnya namun kaya secara spiritual juga mengalami penurunan dari 0.56 menjadi $0.21 \%$. Indeks kemiskinan spiritual menggambarkan jumlah rumah tangga mustahik yang masuk ke dalam kategori miskin secara spiritual tetapi kaya secara material. Indeks kemiskinan spiritual rumah tangga mustahik mengalami perubahan dari 0.08 menjadi $0.01 \%$. Indeks kemiskinan absolut 
menggambarkan jumlah rumah tangga mustahik yang masuk ke dalam kategori miskin secara material maupun secara spiritual.Rumah tangga pada kategori ini mengalami perubahan dari 0.11 menjadi $0.02 \%$.

\section{KESIMPULAN}

Penyaluran dana zakat memiliki dampak yang positif terhadap pendapatan rumah tangga mustahik. Model CIBEST merupakan Model untuk menguji tingkat kemiskinan masyarakat bukan hanya kemiskinan materil namun juga spritual mustahik. Skor spritual pada mustahik dalam penelitian ini diperoleh dari Uji T Statistik berpasangan hasilnya adalah signifikan sebesar 0.0000 artinya terdapat perbedaan skor spiritual mustahik tanda dan adanya zakat. Artinya dengan adanya zakat perbedaannya bukan hanya peningkatan ekonomi keluarga saja namun juga secara spritual. Spritual yang diukur melalui model CIBEST ini adalah Shalat, Puasa, Zakat, Lingkungan Rumah Tangga dan Kebijakan Pemerintah. Berdasarkan Model CIBEST ini maka bisa dianalisis bahwa sebelum adanya bantuan zakat tingkat Kemiskinan pada masing masing kuadran terlihat pada tabel $\mathrm{di}$ atas. Kuadran 1 area sejahtera ada 25 Rumah Tangga, Kuadran 2 Miskin Materil sebanyak 56 Rumah Tangga, sementara pada kuadran 3 Miskin Spritual sebanyak 8 Rumah Tangga dan Miskin Absolut pada kuadran 4 sebanyak 11 Rumah Tangga. Setelah memperoleh bantuan dana zakat maka berdasarkan data yang diperoleh sesuai dengan tabel di atas mengalami perubahan pada area kuadran CIBEST. Area Sejahtera sebanyak 76 Rumah Tangga, pada kuadran 2 area Miskin Material sebanyak 21 Rumah Tangga mengalami penurunan dimana sebelum menerima zakat ada sebanyak 56 Rumah Tangga, artinya ada rumah tangga yang mengalami peningkatan ekonomi karena adanya bantuan zakat. Sementara pada area 3 miskin spritual ada 1 Rumah
Tangga, kuadran ini juga mengalami penurunan setelah adanya bantuan zakat artinya dengan adanya bantuan zakat ini ada rumah tangga yang mengalami peningkatan secara spritual. Pada kuadran 4 miskin absolute sebanyak 2 Rumah Tangga.

\section{DAFTAR PUSTAKA}

Beik, Irfan Syauqi \& Arsyianti, LD. 2015. Ekonomi Pembangunan Syariah. IPBPress. Bogor.

Beik, Irfan Syauqi. 2009. Analisis Peran Zakat dalam Mengurangi Kemiskinan: Studi Kasus Dompet Dhuafa Republika. Jurnal Pemikiran dan Gagasan. 2(1), 1-11.

BPS. 2018. Pekanbaru dalam Angka 2018. Badan Pusat Statistik. Kota Pekanbaru.

Hafidhuddin, Didin \& Pramulya, R. 2008. Kaya Karena Berzakat. Penebar Swadaya. Jakarta.

Mubarokah, Isro'iyatul., Beik, Irfan Syauqi \& Irawam, Toni. 2017. Dampak Zakat terhadap Kemiskinan dan Kesejahteraan Mustahik (Kasus : BAZNAS Provinsi Jawa Tengah). Jurnal Al Muzara'ah, 5(1), 37-50.

Mushlihah, Nida. 2016. Analisis Dampak Pendistribusian Dana Zakat Sebagai Pengurang Kemiskinan Dengan Menggunakan Model Cibest (Kasus: Laz Pm Al Bunyan Kota Bogor). IPB. Bogor.

Prastyo, AA. 2010. Analisis FaktorFaktor yang Mempengaruhi Tingkat Kemiskinan. UNDIPPRESS. Semarang. 